\title{
INVESTIGATION OF THE CORROSION BEHAVIOR OF COOLING COIL MATERIAL IN A SIMULATED CONCRETE ENVIRONMENT (U)
}

by

\section{B. J. Wiersma}

Westinghouse Savannah River Company

Savannah River Site

Aiken, South Carolina 29808

RECOIYED

MAY 101993

OST1

This paper was prepared in connection with work done under the above contract number with the U. S. Department of Energy. By acceptance of this paper, the publisher and/or recipient acknowledges the U. S. Government's right to retain a nonexclusive, royalty-free license in and to any copyright covering this paper, along with the right to reproduce and to authorize others to reproduce all or part of the copyrighted paper. 


\section{DISCLAIMER}

This report was prepared as an account of work sponsored by an agency of the United States Government. Neither the United States Government nor any agency thereof, nor any of their employees, makes any warranty, express or implied, or assumes any legal liability or responsibility for the accuracy, completeness, or usefulness of any information, apparatus, product, or process uisclosed, or represents that its use would not infringe privately owned rights. Reference herein to any specific commercial product, process, or service by trade name, trademark, manufacturer, or otherwise does not necessarily constitute or imply its endorsement, recommendation, or favoring by the United States Government or any agency thereof. The views and opinions of authors expressed herein do not necessarily state or reflect those of the United States Government or any agency thereof.

This report has been reproduced directly from the best available copy.

Available to DOE and DOE contractors from the Office of Scientific and Technical Information, P.O. Box 62, Oak Ridge, TN 37831; prices available from (615) 576-8401, FTS 626-8401.

Available to the public from the National Technical Information Service, U.S. Department of Commerce, 5285 Port Royal Rd., Springfield, VA 22161. 

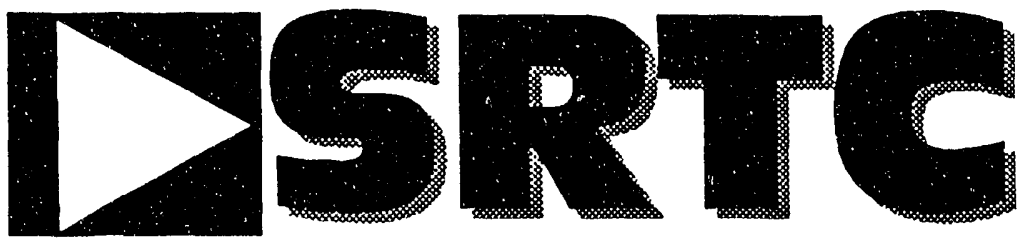

Savannah RIver Technology Center

\section{Equipment and Materials Technology Materials Technology Section}

To: B. L. Lewis, 703-H

From: B. J. Wiersma, 773-A B.f. Them

Approved By:

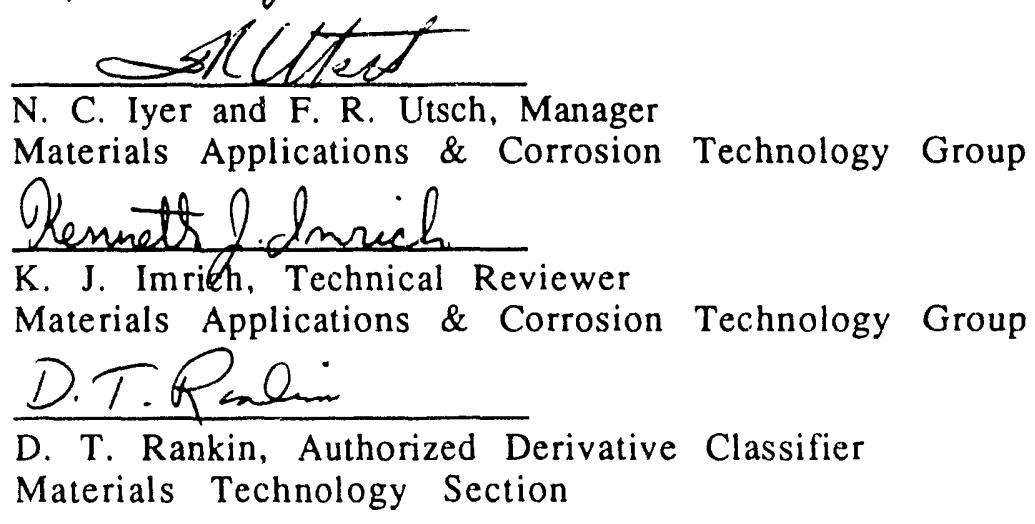

Investigation of the Corrosion Behavior of Cooling Coil Material in a Simulated Concrete Environment (U)

\section{Summary}

Pitting corrosion of the cooling coils embedded in the concrete roof of the waste tanks is one of the suspected causes of the recent cooling coil failures. Cyclic polarization tests were conducted to predict the threshold chloride level above which pitting would initiate. The threshold chloride level was determined to be $9000 \mathrm{ppm}$. Although these tests predict the electrochemical or corrosion behavior of the metal, they may not predict the severity of attack. Further tests which investigate the effect of the permeability of the concrete matrix on the transport of water and oxygen to the metal surface are planned to assess the severity of attack. 


\section{Introduction}

Cooling coils remove radioactive decay heat in high heat waste tanks. Recently, several coils in Type III waste tanks failed, particularly in Tanks 38, 48, and 50.1 Tanks 48 and 50 are crucial since they are part of the In-Tank Precipitation (ITP) process which produces feed for the Defense Waste Processing Facility (DWPF). When a coil fails it is blanked-off, which reduces the cooling capacity for the waste tank. If a sufficient number of coils fail, the waste temperature will begin to rise. Due to the temperature increase, additional nitrite inhibitor would be required to prevent pitting corrosion of the primary tank walls. Additional nitrite is undesirable because of the deleterious effects of nitrite on the DWPF process.

To date there have been no quantitative investigations into the precise location of the leaks in the Type III tanks or the mechanism by which they occur. There are however, two regions where leaks in the cooling coils are suspected to initiate: the concrete roof and the vapor space above the liquid level in the tank. A task plan was proposed to investigate corrosion mechanisms which may occur in these areas. ${ }^{2}$ This report summarizes experimental tests to determine the pitting susceptibility of the cooling coils embedded in the concrete roof.

The concrete environment generally provides a protective environment for embedded metals. During cement hydration a passive oxide film is formed on metals which prevents corrosive attack. This passive film is maintained by the alkaline solution ( $\mathrm{pH}$ $\sim 12-13$ ) present in the pore matrix of the concrete. However, chloride ions from the environment may penetrate the concrete matrix, via the "pore water", and breakdown this passive oxide film thereby initiating localized attack. The literature suggests that there is a threshold $\mathrm{Cl}^{-} / \mathrm{OH}^{-}$level for the pore water above which embedded iron will begin to depassivate. ${ }^{3}$ Two analyses were performed to study this mechanism. First, a small concrete chip was taken from the top of the tank in the valve house. The chip was then analyzed for chloride content. The second step involved electrochemical tests to determine the threshold $\mathrm{Cl}^{-} / \mathrm{OH}^{-}$level for the cooling coil material. 


\section{Results}

\section{A. Cooling Coil and Concrete Material}

The cooling coils in Type III tanks are $2 "$ Schedule 40 piping and are fabricated from ASTM A106 carbon steel (A106). Sections of pipe were removed from blanked-off coils in the valve houses of Tanks 38,40 , and 48 . These sections were then cut into small samples for the electrochemical tests. The composition of the A106 used in Tanks 38-43 (Project No. 9S1618) was obtained from Certified Mill Test Reports (CMTR) and is shown in Table 1. The microstructure was examined and found to consist primarily of ferrite and pearlite with small manganese sulfide inclusions. ${ }^{4}$

The concrete chips from the tank top were analyzed by $x$-ray diffraction (XRD), x-ray florescence (XRF), and by quantitative chemical analysis. The XRD analysis showed that the concrete consists of silicon oxide (sand or quartż), calcium hydroxide (cement), calcium carbonate and calcium aluminum silicate hydrate. XRF and chemical analysis were performed to determine the chloride content of the concrete. A procedure from ASTM C114 was used to determine the amount of acid soluble chloride present in the concrete. 5 Duplicate tests indicated that the acid soluble chloride content was approximately $5 \mathrm{ppm}$. XRF also indicated that the chloride content was on the order of $10 \mathrm{ppm}$. This chloride level will be used in the electrochemical tests to determine the threshold $\mathrm{Cl} / \mathrm{OH}^{-}$ratio.

\section{B. Electrochemical Tests}

Cyclic polarization tests were conducted to determine the pitting susceptibility of the archived A106 in a simulated concrete environment. For these tests, a specimen is immersed in a solution and a potential is applied. The potential is scanned from a value near the open circuit potential to a more positive value while the current density of the sample is monitored. When the current density reaches approximately $5 \mathrm{~mA} / \mathrm{cm}^{2}$, the scan is reversed and the potential is returned to the open circuit potential. If the current density of the reverse scan is greater than the current density of the forward scan, pitting susceptibility is indicated. Conversely, if the forward scan current density is greater than the reverse scan current density there is no pitting. The plot shown in Figure 1 shows the plot of potential (E) versus log current density (I/area) for a sample 
which indicates attack. Pitting is verified at the end of the test by visual examination of the sample.

An EG\&G Princeton Applied Research (PAR) Model 273

Potentiostat/Galvanostat was used to perform these tests. The tests were controlled from an IBM PS/2 Model 70 computer which uses PAR Model 352 Software. The electrochemical test cell includes the working electrode (i.e., test specimen), the counter-electrode, and the reference electrode against which the potential is measured. A saturated calomel electrode (SCE) was used as the reference electrode for these tests.

Concrete environments are frequently simulated with a pore water solution. 6 The pore water is similar to the solution that forms when the cement and water are mixed. Table 2 shows the molar anion concentration and $\mathrm{pH}$ of the pore water. Chloride additions (i.e., sodium chloride) were made to the pore water to determine the threshold ratio for pitting of A106. The tests were conducted at $23^{\circ} \mathrm{C}$.

The test results are shown in Table 3 and indicate that the threshold ratio for $\mathrm{Cl}^{-} / \mathrm{OH}^{-}$is approximately 0.3 . This value converts to a pore water chloride level of $9000 \mathrm{ppm}$. The literature suggests that other carbon steels, such as concrete reinforcement bar, have a similar threshold chloride level. ${ }^{7}$ These results coupled with the amount of chloride measured previously suggest that the chloride level in the concrete is not sufficient to initiate pitting. This conclusion however, assumes that the chloride concentration is uniform throughout the concrete matrix which may or may not be the situation. In fact, the valve house, where the concrete chip was taken, is protected from the environment and would probably show little change between the initial chloride content of the concrete and the present chloride content. There may be other areas of the tank roof which are exposed to chloride containing environments. More information on the environment and quality of the concrete exposed to the elements is necessary to make a complete assessment.

Although these tests can predict the electrochemical or corrosion behavior of the embedded metal, they do not necessarily predict whether or not corrosion will be severe in the concrete environment. ${ }^{8}$ The severity of attack is controlled by the ability of water and oxygen to diffuse through the concrete matrix. The transport capabilities of these species are related to the permeability 
of the concrete matrix. If the resistance to water diffusion is significant, chloride diffusion to the metal surface will be restricted. A high resistance would also limit the corrosion current which may flow between the anodic and cathodic regions on the metal surface. Limiting the availability of oxygen may also lower the corrosion rate by reducing the rate of the cathodic reaction. However, if certain sections of the metal are exposed to oxygen, while others are deprived, an oxygen concentration gradient would result. This condition may result in severe macrocell corrosion if the resistance to current flow is not significant. Again, a more thorough assessment of the quality of the concrete will be necessary to predict the possibility of severe attack.

\section{Conclusions and Future Work}

The electrochemical tests indicate that if the chloride level in the vicinity of the cooling coil exceeds $9000 \mathrm{ppm}$, pitting will be initiated even in extremely alkaline environments. The chloride content of the concrete chip taken from the valve husse indicated that the chloride level was approximately $10 \mathrm{ppm}$, well below this threshold value. However, the location where the chip was removed may not represent the worst case (i.e., highest chloride content). In addition, in order to fully assess the possibility for severe attack, the permeability of the concrete must be considered.

Tests are being planned which will attempt to simulate the permeability of the concrete matrix. Coupons of A106 material will be embedded in sand. Pore water, with given chloride levels (i.e., similar to those used in the electrochemical tests), will then be poured over the sand. These tests will simulate the diffusion of chloride, water and oxygen to the cooling coil surface and hence the possibility of attack. In addition a thorough review of concrete specifications and quality assurance records will be performed to detcrmine the initial quality of the concreti.

\section{References}

1. W. R. West, H. D. Bennett, and V. C. Sharma, "Cooling Coil Update", a HLWE Bi-weekly Report, WSRC, October 27, 1992.

2. B. J. Wiersma to B. L. Lewis, "Investigation of the Mechanical and Corrosion Behavior of the Cooling Coil Material from the SRS Waste Tanks (U)", SRT-MTS-92-3026, May 28, 1992. 
3. D. A. Hausmann, Materials Protection, Vol. 6, No. 19, Nov. 1967, pp. 19-23.

4. B. J. Wiersma, "Measurement of the Ductile to Brittle Transition Temperature for Waste Tank Cooling Coils (U)", WSRC-TR-92-444, September 1992.

5. ASTM Standard C114-88, "Chemical Analysis of Hydraulic Cement", ASTM, Philadelphia, PA, 1991.

6. H. Arup in "Solving Rebar Corrosion Problems in Concrete", NACE, Houston, TX, 1983.

7. "Corrosion of Metals in Concrete", ACI Journal, Jan.-Feb. 1985, pp. 3-32.

8. J. L. Dawson and P. E. Langford, "The Electrochemistry of Steel Corrosion in Concrete Compared to its Response in Pore Solution" in The Use of Synthetic Environments for Corrosion Testing, ASTM STP 970, P. E. Francis and T. S. Lee Eds., ASTM, Philadelphia, Pa., 1988, pp. 264-273.

Table 1. Composition of A106 Cooling Coil and Reference Materials

\begin{tabular}{|c|c|c|c|c|c|c|}
\hline Heat & $\% \mathrm{C}$ & $\% \mathrm{Mn}$ & $\% \mathrm{P}$ & $\% \mathrm{~S}$ & $\% \mathrm{Si}$ & $\% \mathrm{Fe}$ \\
\hline $\mathrm{T} 48602$ & 0.21 & 0.77 & 0.004 & 0.022 & 0.15 & $\mathrm{~b} \mathrm{al}$ \\
\hline $\mathrm{D} 46140$ & 0.22 & 0.72 & 0.004 & 0.015 & 0.16 & $\mathrm{~b} \mathrm{al}$ \\
\hline $\mathrm{L} 45685$ & 0.25 & 0.81 & 0.012 & 0.018 & 0.17 & $\mathrm{~b} \mathrm{al}$ \\
\hline L45708 & 0.23 & 0.66 & 0.008 & 0.019 & 0.16 & $\mathrm{~b} \mathrm{al}$ \\
\hline L45720 & 0.22 & 0.73 & 0.013 & 0.019 & 0.19 & $\mathrm{~b} \mathrm{al}$ \\
\hline F110 (ref.) & 0.22 & 0.92 & 0.019 & 0.014 & 0.24 & $\mathrm{~b} \mathrm{al}$ \\
\hline
\end{tabular}


Table 2. Pore Water Molar Ion Composition (M)

\begin{tabular}{|c|c|}
\hline Ion & Concentration \\
\hline $\mathrm{Na}^{+}$ & 0.3 \\
\hline $\mathrm{K}^{+}$ & 0.6 \\
\hline $\mathrm{Ca}^{++}$ & 0.002 \\
\hline $\mathrm{OH}^{-}$ & 0.85 \\
\hline $\mathrm{SO}_{4}=$ & 0.03 \\
\hline $\mathrm{pH}$ (calc.) & 13.9 \\
\hline
\end{tabular}

Table 3. Results of Cyclic Polarization Tests in Pore Water

\begin{tabular}{|c|c|c|}
\hline$\left[\mathrm{Cl}^{-}\right]$Conc. $(\mathrm{M})$ & {$\left[\mathrm{Cl}^{-}\right] /\left[\mathrm{OH}^{-}\right]$} & Pitting (Y/N) \\
\hline 0 & 0 & No \\
\hline 10 & 0.00033 & No \\
\hline 100 & 0.0033 & No \\
\hline 500 & 0.017 & No \\
\hline 1000 & 0.033 & No \\
\hline 5000 & 0.17 & No \\
\hline 7500 & 0.25 & No \\
\hline 9000 & 0.3 & Yes \\
\hline 15,000 & 0.5 & Yes \\
\hline 18,000 & 0.6 & Yes \\
\hline
\end{tabular}




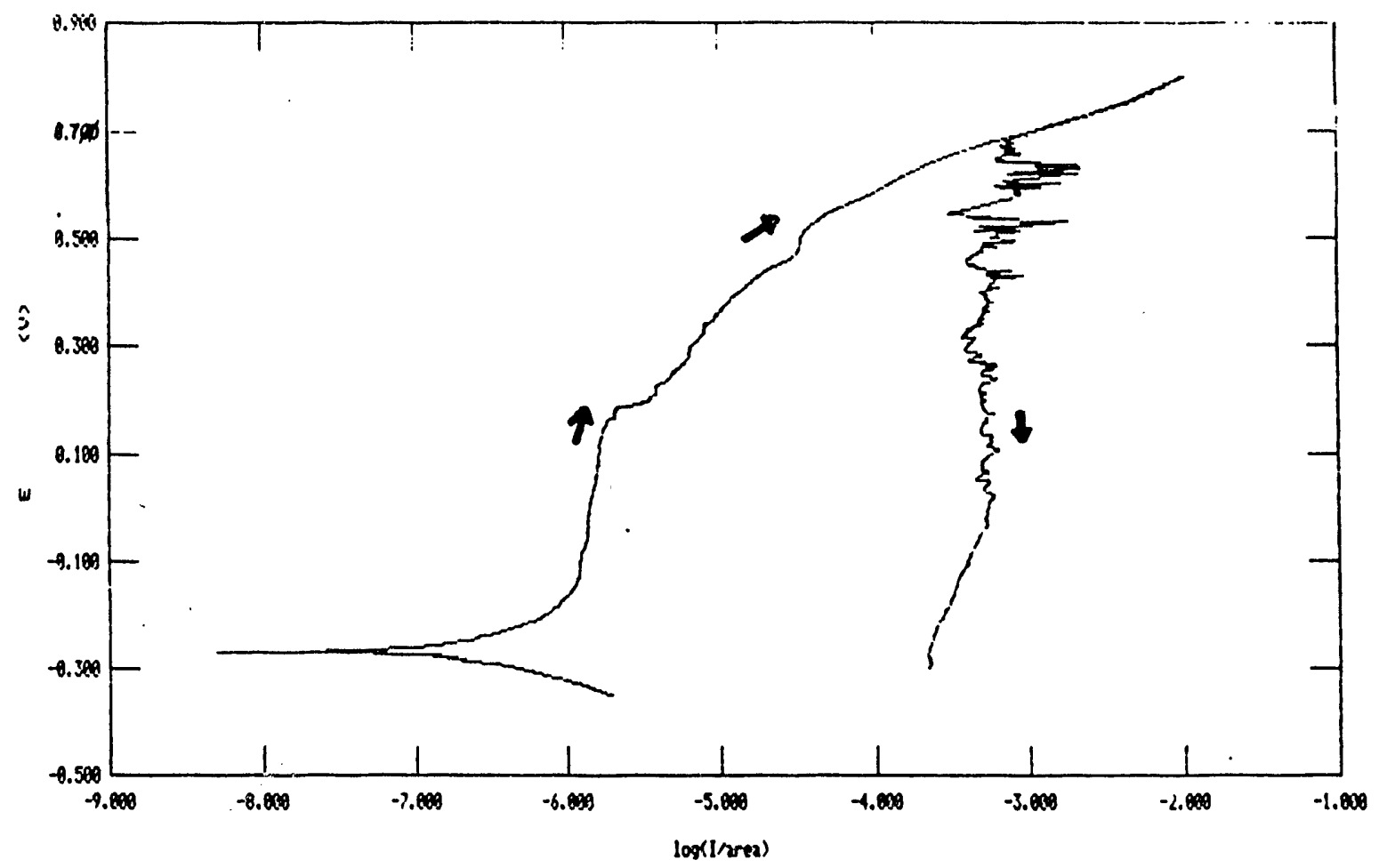

Figure 1. Cyclic polarization test on A106 carbon steel in pore water with $15,000 \mathrm{ppm} \mathrm{Cl}^{-}$. Note that pitting susceptibility is indicated. 

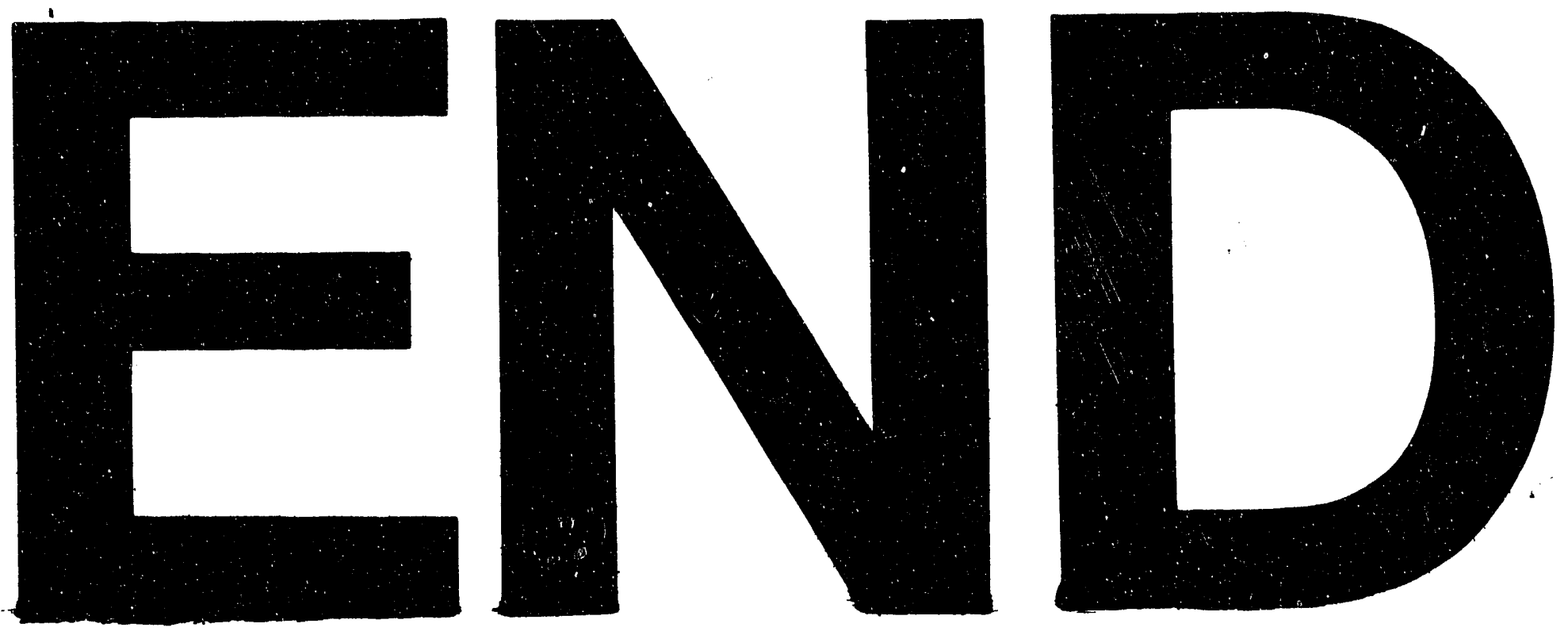

28
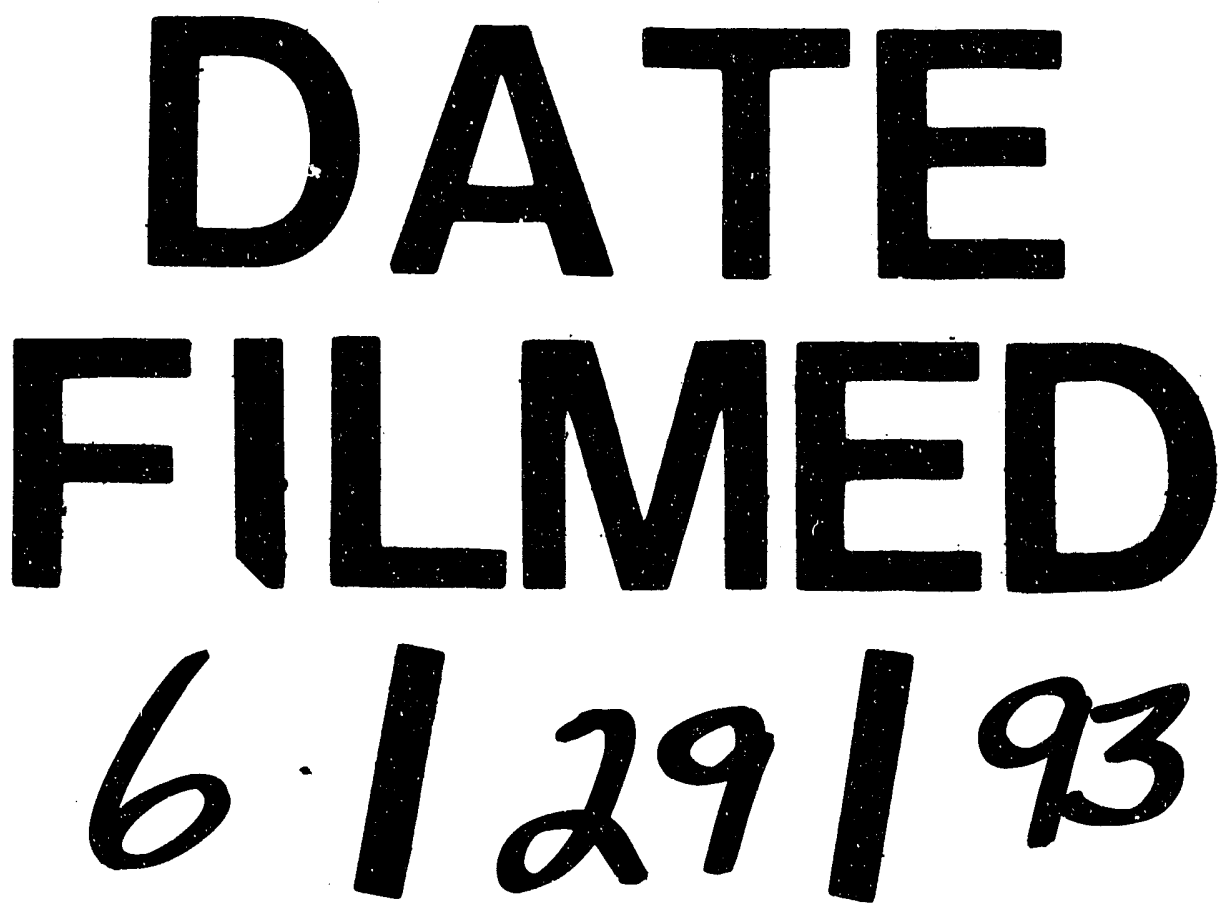
$\therefore$

- 